\title{
Carcinoma of esophagus, salivary gland type
}

INSERM

\section{Source}

INSERM. (1999). Orphanet: an online rare disease and orphan drug data base. Carcinoma of esophagus, salivary gland type. ORPHA:418945

\# 8208; lining epithelial and myoepithelial cells with tubular, cribriform, solid, or basaloid growth patterns). Patients may be asymptomatic or may present with progressive dysphagia, heartburn, retrosternal pain and/or weight loss. 